ance during a power outage" (p.230). Synergism is in the food we eat, the baking of a lemon pie, personal health, the telephone system, insurance, shopping centres, multiple movie theatres (p.233). So that's what Adam Smith has in common with a supermarket?

Beneath his grandiose rhetoric and camouflaged by his heavy reference list, Dr Corning is calling attention to the modest but unfortunately not self-evident statement that reductionism is an inadequate programme for the scientific understanding of living organisms or the societies they construct. Although it is not clear why the author thinks he has contributed significantly to the debate over the limits to the reductionist programme, there is no doubt that his book has been written in reaction to claims made even more stridently than his own - those of sociobiology. E.O. Wilson's ludicrous claim that "The development of fundamental theory in sociology must await the full neuronal explanation of the brain" stands, an epigram contrasted with others by Durkheim and Gould, at the head of one major chapter. Dawkins's "lumbering robots" programmed by those misbegotten "selfish genes" lurk wolfishly in Corning's pages to be stripped yet again of their skins to reveal the sheep they really are.

Complex wholes are not reducible to ontologically prior parts; systems have properties which are not dissociable into, or strictly predictable from, the units of which they are composed. New properties emerge with complexity, and genes should no more be described as selfish or aggressive than should humans be regarded as subject to Van der Waal's forces or Brownian motion. Laws of motion descriptive of one level of organization of matter are not translatable, holus-bolus, to another. That these statements are not self-evident is due to the ideological power of reductionism, not least within the pages of Nature. Therefore, I must, in principle, welcome Dr Corning to the side of the good and the true who fight the brave fight against reductionism.

However, mine enemy's enemy is not always to be seen as unequivocally clearheaded and right-minded. In his eagerness to defeat the reductionist myth, Dr Corning elevates synergism itself to the great organizing principle of nature much as Engels once did for the dialectic. Oddly The Dialectics of Nature does not appear to be part of Dr Corning's otherwise omnivorous reading, albeit his list of examples of synergism reads uneasily like Engels's claims to find the transformation of quantity into quality in the boiling of water, and the interpenetration of opposites in the north and south poles of a magnet.

Despite Dr Corning's clarity in avoiding the trap of reducing individual social actions to the mere motions of molecules, he oddly fails to avoid the trap of seeing society as composed of individuals whose market-like relationships conform to some cybernetic principle or other. Whether individuals choose to act socially, he implies, is their own affair - as if they at least were free. Faced with the problems this might entail, he weakly invokes Sperry's principle of downward causation as if this might spring the trap. The consequence is that whilst his early chapters on Darwin, progressive evolution and interactionism are merely platitudinous and longwinded, his final chapter on a "general theory of politics" is downright inadequate. A theory of politics which has no place for conflict - of class, gender or race - and which sees no theoretical difference between socialism and capitalism, is frankly out of place in anything except, apparently, a Stanford Political Science class. It

\section{Between Brussels and Westminster}

\section{Eric Ashby}

EEC Environmental Policy and Britain:

An Essay and a Handbook.

By Nigel Haigh.

Environmental Data Services, Unit 24, Finsbury Business Centre, 40 Bowling Green Lane, London: 1984. Pp.324. Pbk 1 12.95, \$25.

The Pollution Control Policy of the European Communities, 2nd Edn. By Stanley P. Johnson.

Graham \& Trotman, Sterling House, 66 Wilton Road, London: 1983.

Pp.244. £18.

"As BEFITS the genius of Europe, particular attention will be given to intangible values and to protecting the environment. ..". This burst of rhetoric was issued by the heads of state or government in the European Community, when they met in 1972. It is the foundation for an environmental policy for Europe. A weak foundation, in the opinion of some lawyers, for the legal basis of the European Community is the Treaty of Rome; the purpose of the Treaty is to establish free trade between member states. To this end the member states agree to approximate (or "harmonize") their national laws in so far as they "directly affect the establishment or functioning of the common market". Laws to protect the environment are, so these lawyers say, irrelevant to the Treaty unless it can be demonstrated that they "directly" affect trade.

This is no legalistic quibble. An important principle is at stake. Every item of Community law agreed to by a member state involves a corresponding surrender of sovereignty by that state. Directives from the Community, once agreed, have the force of international law. Therefore if Britain acquiesces in some Community law to protect the environment and which has no direct effect on the functioning of the is in this chapter that Dr Corning compares his two Californian hospitals, one cybernetically run, "lean, highly efficient" and generating a satisfactory profit; the second lax, with a "chit-chat culture" which turns a loss to its investors. There is no doubt which Dr Corning prefers. But his account fails to tell us which of these two hospitals has a better patient recovery rate, and in which of the hospitals the patients feel happiest. Could there just be something missing from his Grand Unified Theory?

Steven Rose is Professor of Biology at the Open University. With R. C. Lewontin and L. Kamin, he is author of Not in our Genes to be published later this year by Penguin and Pantheon.

common market, there may be a risk (to quote the words of one of Britain's law lords) of "a creeping surrender of our national sovereignty in almost unlimited fields of law". Well, we have taken the risk.

The Declaration of 1972 has the authority of a moral exhortation and nothing more. It is, for me, a cheering sign of sanity that Britain, though not even a signatory to the 1972 Declaration, has acquiesced - though often with ill grace in many environmental directives from Brussels. The ill grace was not without provocation: the drafting of some of the directives was ham-fisted, not to say stupid; and Britain, having been the first European nation to despoil her environment, has learnt, better than any other European nation, how to repair the damage. So Britain had valuable experience to offer Europe. Has the offer been welcomed? On the whole, no. Nevertheless Britain has accepted the moral, if not legal, obligation to surrender some sovereignty over the control of her own air, water and land. Mr Haigh's book is a critical study of this unrecorded and remarkable influence of the Community on British policy.

If Mr Haigh has a fault, it is an excess of modesty. He calls his volume a "handbook" accompanied by an "essay". It is in fact a penetrating and perceptive analysis of the evolution of an environmental policy for Europe and Britain's response to it; written with scrupulous regard for accuracy and fairness; critical in places but always courteously so; offering opinions of his own which are clearly the result of very careful assessment of a mass of material: a book of outstanding quality. The only justification for calling it a handbook is the systematic way in which the case-studies of over thirty Commission documents are treated; for each one there are the formal particulars, a summary of the content, and an account of how it developed and its effect on practice in the United Kingdom.

In his introductory essay, $\mathrm{Mr}$ Haigh describes the historical and administrative 
framework into which Community law has to be set. Immediately the problems appear. It is British policy to delegate responsibility and discretion to local authorities; to impose a blanket-regulation from Brussels upon a county council or a regional water authority is to weaken this cherished tradition. It is British policy, too, to be deliberately imprecise over some matters (was it not Churchill who said that we never create a distinction without blurring it!). For instance we are content in Britain to prescribe that our drinking water shall be "wholesome"; the European Council Directive of 15 July 1980 on the quality of water for human consumption specifies 63 parameters, from colour to coliform count, which have to be at acceptable levels. No wonder, when a stream of draft directives began to flow into Britain, there was a conflict between the often complacent pragmatism of the British and the often arrogant rigidity of the Europeans across the Channel. The most serious encounter was over the protection of what directives call "the aquatic environment". Do you fix an upper limit to the level of pollutants that can be discharged into the aquatic environment, from a pulp mill or a titanium dioxide works, to be the same from Scotland to Greece? Or do you take into account that the capacity of the receiving water to dilute and disperse the pollutants is greater in the Atlantic Ocean than it is $\mathbf{3 0 0}$ miles up the Rhine; and that it is the quality of the receiving water that should be the criterion for control of pollution?

Mr Haigh, in his case-studies, deals with this and a dozen similar conflicts with sympathy for both sides. On one hand many of the draft directives have been shoddily prepared, with totally inadequate scientific backing - in some instances not even consistent with the scientific advice the Commission itself sought. They deserved, and got, scathing criticism from the House of Lords scrutiny committee set up to deal with directives. On the other hand the British government has often adopted attitudes as pedantic as anything that has come from Brussels; it has on occasion been querulously defensive, and sometimes (for example in citing, in its defence, provisions in the Control of Pollution Act that had not been implemented) downright disingenuous. These and other faults on both sides are dealt with fairly and impartially, but $\mathrm{Mr}$ Haigh disciplines himself severely to keep within his self-imposed terms of reference, which are to examine the influence the Community has had on environmental policy in the United Kingdom. He admits that it is hard to isolate the influence of the Community from other contemporary influences: the ten reports from the Royal Commission on Environmental Pollution, for example, and the pressures from environmental lobbies (to which, in my view, he gives too little weight). But he does make a case for some impact from
Brussels: the belated decision to set (rather than just waffle about) environmental quality objectives in rivers; the agreement to adopt mandatory air quality standards for sulphur dioxide and particulates; some features of the Wildlife and Countryside Act; and (a more dubious benefit) the substitution of control by regulation in place of voluntary agreements (which for detergents had been entirely successful).

The chapter on the British influence on the Community is brief, but that is not what the book is about. I'm sorry, however, that $\mathrm{Mr}$ Haigh did not make one point which would, if the Commission in Brussels would listen, greatly smooth the path of negotiation over directives. That is to demand that the Commission should publish regularly, from the mass of data it receives, comparable figures to show the different degrees of compliance among member states with these directives. From several sources one can see the trend in sulphur dioxide emissions in Britain over the past ten years; one can see also the changes in the mileage of rivers of different qualities; the levels of dust in the air; and so on. But where can one find, so easily accessible, data from any other member state in the Community? And how, without such baselines for environmental trends in each member state, can one devise an environmental strategy for Europe? The EEC has dismally failed to provide these comparative data. Summaries in the Environmental Action Programmes are worthless, for they have nothing to say about the implementation of the laws that look so good on paper.

Mr Stanley Johnson's book, like the official publications from the European Commission, contains a suave sanitized version of the environmental legislation, with scarcely a hint of the controversies and political scheming that have so often distorted its intentions. The book, despite its pretentious title, is (as $\mathrm{Mr}$ Johnson admits) "purely documentary", an assembly of texts, all of them already published. In places it goes into tedious detail, giving (for instance) the full names of 129 chemicals that could belong to the notorious "black list" of substances to be "eliminated" from the aquatic environment. It is useful to have in one volume a catalogue of the environmental directives; but such critical assessments as the book contains are as bland as those one finds in a mail-order catalogue. It is disappointing that the vice-chairman of the European Parliament's Committee on Environment can offer nothing more than this. In contrast, Mr Haigh's book is a solid contribution to the debate on an environmental strategy for Europe.

Lord Ashby serves on the House of Lords subcommittee which scrutinizes draft directives on environmental issues from the European Commission. He was chairman of the Royal Commission on Environmental Pollution from 1970 to 1973.
New Titles from Pitman

\section{Mechanisms of Alcohol Damage in utero Ciba Foundation Symposium 105}

Chairman: O E Pratt, Department of Neuropathology, Institute of

Psychiatry, London.

This volume brings together recent basic and clinical research on how alcohol affects the developing embryo and fetus. Emphasis is placed on the

basic mechanisms of action on

alcohol, but studies of affected

children and discussions of how to discourage drinking during pregnancy are also considered.

To be published May 1984

Cased $/ 229 \times 152 \mathrm{~mm} / 308$ pages

ISBN $027279774 \mathrm{X} / £ 26.50$

\section{Human Cataract Formation Ciba Foundation Symposium 106}

Chairman: Professor Abraham Spector, Department of Opthalmology, College of Physicians and Surgeons of Columbia University, USA.

This book discusses the latest results in lens research, covering topics from protein genes to epidemiology. Various hypotheses explaining cataract

formation are compared and contrasted in the light of recent research and new techniques for obtaining more information on the mechanism of cataract formation are considered.

To be published July 1984 Cased $/ 229 \times 152 \mathrm{~mm} / 320$ pages approx.

ISBN $0272797758 / £ 26.50$

Functions of the Basal Ganglia Ciba Foundation

Symposium 107

Chairman: Dr Edward Evarts, National Institute of Mental Health, Bethesda, Maryland, USA.

The basal ganglia have been termed 'the dark basement of the brain' and their role in the overall pattern of cerebral function remains obscure.

Both neuroscientists and clinicians will find the topics discussed invaluable to the understandins of the function and clinical importance of this major yet mysterious brain area.

To be published April 1984

Cased $/ 229 \times 152 \mathrm{~mm} / 320$ pages approx ISBN 027279777 4/£26.50

All prices subject to change without notice. Available from your bookseller, or in case of difficulty, from Cashpost Service,

Pitman Publishing Ltd., 128 Long Acre, London WC2E 9AN, England. Telephone: 01-379 7383 . 